\title{
Carlo Beretta, Studio sui rapporti fra i manoscritti rimati della Chanson de Roland
}

\section{Walter Meliga}

\section{(2) OpenEdition}

1 Journals

\section{Edizione digitale}

URL: https://journals.openedition.org/studifrancesi/38877

DOI: 10.4000/studifrancesi.38877

ISSN: 2421-5856

\section{Editore}

Rosenberg \& Sellier

\section{Edizione cartacea}

Data di pubblicazione: 1 décembre 2004

Paginazione: 330-331

ISSN: 0039-2944

\section{Notizia bibliografica digitale}

Walter Meliga, «Carlo Beretta, Studio sui rapporti fra i manoscritti rimati della Chanson de Roland», Studi Francesi [Online], 143 (XLVIII | II) | 2004, online dal 30 novembre 2015, consultato il 19 mai 2021. URL: http://journals.openedition.org/studifrancesi/38877 ; DOI: https://doi.org/10.4000/studifrancesi. 38877

Questo documento è stato generato automaticamente il 19 mai 2021.

\section{(c) (1)}

Studi Francesi è distribuita con Licenza Creative Commons Attribuzione - Non commerciale - Non opere derivate 4.0 Internazionale. 


\title{
Carlo Beretta, Studio sui rapporti fra $i$ manoscritti rimati della Chanson de Roland
}

\author{
Walter Meliga
}

\section{NOTIZIA}

CARLO BERETTA, Studio sui rapporti fra i manoscritti rimati della Chanson de Roland, Potenza, Università degli Studi della Basilicata, 2000, pp. 160 [(“Annali della Facoltà di Lettere e Filosofia dell'Università degli Studi della Basilicata")].

1 Il libro ha per oggetto un'analisi accurata della famiglia di manoscritti che trasmettono la cosiddetta "versione rimata" della Chanson de Roland, analisi mai tentata nella pur lunga e ricca storia dalla filologia rolandiana. La precisa definizione dei rapporti che intercorrono fra i testimoni, illustrati da stemmi e dimostrati da molti riscontri testuali, consentirà una sicura ricostruzione della tradizione rimata della Chanson. 